\section{Student Learning Experience and Student Retention Strategies: A Transformative Approach to Quality Education}

Suwastika Naidu ${ }^{1}$, Arvind Patel ${ }^{2}$, Atishwar Pandaram ${ }^{2}$ and Anand Chand ${ }^{1}$

${ }^{1}$ School of Management and Public

Administration, Faculty of Business and Economics, University of the South Pacific, Suva, Fiji

${ }^{2}$ The University of the South Pacific, Suva, Fiji

\section{Definitions}

$\begin{array}{ll}\text { Retention } & \text { The student retention rate is } \\ \text { rates } & \text { usually calculated as a percentage. } \\ & \text { It measures the percentage of } \\ \text { students who have progressed } & \text { from the first to second and third } \\ & \text { year of their education. } \\ \text { Graduation } & \begin{array}{l}\text { The student graduation rates } \\ \text { measure the number of students } \\ \text { rates }\end{array} \\ & \begin{array}{l}\text { who have completed their studies } \\ \text { and have attained their certificates }\end{array} \\ & \text { after the completion of their } \\ & \text { program. }\end{array}$

Student These are the specific actions taken retention by administrators and leaders to strategies retain students in the institutions.

\begin{abstract}
Some of the common examples of student retention strategies are reducing the cost of fees and acquiring accreditation for programs and courses.
\end{abstract}

\section{Introduction}

The Sustainable Development Goals (SDGs) on quality education emphasizes that reducing disparities and inequalities related to the provision of primary, secondary, and tertiary education (UNESCO 2020; Aarts et al. 2020). An improvement in student retention rates is one of the critical indicators that help the policymakers and practitioners to determine how effectively the national economies are progressing towards addressing income disparities, and addressing the constraints associated with the provision and delivery of education to everyone, irrespective of their gender, age, income, and ethnicity (United Nations 2020; Aarts et al. 2020). By drawing on the formal and informal social networks that exist in communities, the importance of completing education has reached out to all income cohorts in the society. Undoubtedly, parents, community leaders, policymakers, and institution administrators have effectively disseminated the importance of achieving quality education and the impact of this micro-level achievement on the society (Ghee 1990; Simac et al. 2019). The schooling journey has always been subject to numerous challenges, and it is the role of the education 
providers to ensure that the curriculum is designed to provide inclusive and quality education to all the individuals in society (UNESCO 2020; Aarts et al. 2020). The primary objective of the SDG on quality education can only be realized if the students complete their primary, secondary, and tertiary education, with the core objective of becoming responsible individuals, who can contribute towards wealth generation, addressing inequality by generating new employment opportunities and inspiring youths for civic pride and patriotism (UNESCO 2020; Aarts et al. 2020).

Furthermore, the achievement of the SDG on quality education is hindered when students acquire a placement in primary, secondary, and tertiary institutions, but they are not able to successfully complete their education (UNESCO 2020; Aarts et al. 2020). This chapter places particular emphasis on the higher education providers and explores the reasons behind low student retention and graduation rates, not only in the developing countries but also in the developed countries. One of the best ways of understanding the reasons behind low student retention and graduation rates is to investigate the primary reasons driving the student's decisions to leave their studies.

This chapter is organized as follows: The following section provides an overview of the provision of lifelong learning experience to students, followed by student retention strategies in the global context, quality education and factors driving student retention in higher education institutions, challenges faced in retaining disabled and mentally challenged students, implications of the student retention strategies on the SDGs, and finally conclusion.

\section{Provision of Lifelong Learning Experience to Students}

The lifelong learners are individuals in society, who do not demonstrate complacency in learning and teaching, and this trait of such individuals, not only helps them to become national problem solvers, but they become drivers of sustainable development at the global forefront (UNESCO 2020; Aarts et al. 2020). Importantly, the role of the higher education institutions is to nurture the behavior of students who are natural lifelong learners and also to change the behavior of existing students who demonstrate lack of enthusiasm in their goal achievement (UNESCO 2020; Aarts et al. 2020). The administrators, parents, and instructors, who have control over the internal environment settings surrounding a student, have the capacity to make positive changes to the students learning environment. Astin (1985) argues that the constructivist viewpoint on the relationship between student engagement and institutional factors recognizes that the quality of individuals learning and efforts is determined by the institutional environment surrounding the student. Drawing from this argument, it is critical for the policymakers, administrators, and leaders of higher education to realize that specific interventions can be used to positively guide students in a continuously changing learning environment (Kintu and Zhu 2016; Adams et al. 2020). The institution can provide high-quality resources and numerous programs for students, but it is entirely on the students how they make use of these programs and resources (Kintu and Zhu 2016; Adams et al. 2020). Indeed, fostering engagement of students in the higher education settings is a first step towards changing student's behavior and molding them to becoming lifelong learners, who not only work themselves towards sustainable development but they ensure that they take others along with them (Kintu and Zhu 2016; Adams et al. 2020). Specifically, the interventions designed by higher education institutions to create a continuous learning environment are as follows:

- Student learning support programs: Quality education national frameworks recognizes that all individuals in society, irrespective of their age, background, gender, and disabilities should have provisions and access to institutional support programs that helps them to prepare themselves for a diverse workforce 
(UNESCO 2020; Aarts et al. 2020). Modern higher education institutions provide students with student learning support programs, counseling and disability centre services, and international student support services to enable students to settle in the new learning environment. As student's transit from their first year to second- and third-year programs, the academic demands becomes more challenging, and the performance standards and expectations become much higher (Robotham 2008). These support programs ensure that nontraditional students include single parents, full-time workers, and those who may have joined the tertiary institution after working full time for numerous years (Schuetze and Slowey 2002; Cherrstrom et al. 2019). Student attrition rates are higher as student's transit from their first year to the second year of studies as compared to their transition from the second year to third year studies. The nontraditional students face unique challenges that traditional full-time students do not experience, and the role of the support programs is to provide guidance, emotional support, and advise to students who are struggling with their studies (Cherrstrom et al. 2019). In numerous circumstances, students lack the realization of the importance of these support programs to their successful completion of studies. Essentially, by creating awareness of these programs within the higher education setting, the administrators and leaders ensure that the benefits of these programs reach out directly to the students who require immediate support (Cherrstrom et al. 2019).

- Resources: The provision of equitable and inclusive resources to the students ensures that those who are economically disadvantaged can access these resources and finance their education (UNESCO 2020; Aarts et al. 2020). Governments, higher education institutions, and the private sector have always provided support to the economically disadvantaged students. Most of the scholarships cover travel, subsistence allowance, relocation expenses, and health insurance for students (Straus 2020; Roksa et al. 2020).
These resources not only provide students with economic empowerment but also it ensures that equal opportunities are provided to everyone in society. In addition to these resources, the tertiary institutions provide tutorial rooms, science labs, lecture facilities, and computer labs for students. One of the main stressors for students, particularly the ones from the developing countries, is the lack of accessibility to information computer technologies to complete their assignments and store electronic copies of their study notes (Fichten et al. 2020; Sife et al. 2007). Recent statistics on the information computer technology shows that there are more computers in the USA as compared to the computer resources available to the rest of the world (Granville et al. 2000). Table 1 presents the statistics on household's computer accessibility at home. The household's computer accessibility at home is highest for Europe followed by the Americas, Commonwealth of Independent States (CIS), Arab States, Asia and Pacific, and Africa. The alarming statistics for Africa indicate that students are hardly able to access the computer at home for completing their assignments and school-related work. Undoubtedly, this indicates that students in Africa face severe challenges with resources constraints, particularly, the availability of information computer technology. It is here that the computer labs in universities become a key resource for the students. One of the best ways of increasing student retention in the developing countries where students are facing resource constraints is to ensure that the higher education institutions provide students with the best information computer technology and software's needed to complete assignments and class submissions.

In addition to the computers, the internet also serves as an important resource for the students as students use it daily to check their emails, announcements posted on the online learning system, download learning materials, interacting with their classmate's online, and downloading research materials related to their assignments. 
Student Learning Experience and Student Retention Strategies: A Transformative Approach to Quality Education, Table 1 Households computer accessibility at home

\begin{tabular}{l|l|l}
\hline Areas & Year & Per 100 inhabitants \\
\hline Africa & 2019 & 10.7 \\
\hline Arab States & 2019 & 51.9 \\
\hline Asia and Pacific & 2019 & 43.5 \\
\hline Commonwealth of Independent States (CIS) & 2019 & 66.3 \\
\hline Europe & 2019 & 78.0 \\
\hline The Americas & 2019 & 65.7 \\
\hline
\end{tabular}

Source: International Telecommunications Union (2020)

Student Learning Experience and Student Retention Strategies: A Transformative Approach to Quality Education, Table 2 Percentage of the population using internet

\begin{tabular}{l|l|l}
\hline Area & Latest year & Percentage \\
\hline Caribbean Small States & 2016 & $53.56 \%$ \\
\hline Central Europe and Baltics & 2016 & $71.35 \%$ \\
\hline East Asia and the Pacific & 2016 & $52.95 \%$ \\
\hline Europe and Central Asia & 2016 & $63.46 \%$ \\
\hline European Union & 2016 & $80.13 \%$ \\
\hline Fragile and conflicted affected situations & 2016 & $18.11 \%$ \\
\hline Heavily indebted poor countries & 2016 & $16.08 \%$ \\
\hline High income & 2016 & $81.66 \%$ \\
\hline Latin America and the Caribbean & 2016 & $57.40 \%$ \\
\hline Least developed countries & 2016 & $15.65 \%$ \\
\hline Low income & 2016 & $13.60 \%$ \\
\hline Middle income & 2016 & $41.77 \%$ \\
\hline
\end{tabular}

Source: World Bank database (2020)

Table 2 shows the percentage of the population using the internet in different geographical regions of the world. The statistics show that $81.66 \%$ of the population in the high-income countries are using the internet as compared to $13.60 \%$ in low-income countries. This indicates that the students in the high-income countries are in an advantageous position as compared to the students in low-income countries. The role of the higher education administrators and leaders becomes essential in this context, mainly, in the provision of internet services within the education facility.

- Instruction delivery: The new millennium has brought us new challenges in the design and delivery of higher education. There are numerous factors that higher education institutions need to consider to make the delivery of higher education inclusive and equitable to everyone in society (UNESCO 2020; Aarts et al. 2020). Rapid technological changes, diversity, and changes in industry demands have made the instruction delivery of higher education courses more challenging, as the providers of higher education are required to deliver courses that suit the changing needs of the different stakeholders. The instruction delivery of the online and blended learning courses differs significantly from the delivery of the face-to-face courses. Universities usually target distance learners for their online and blended learning courses, and most of these courses are delivered on an interactive information computer technology platform. This modern decade quest of universities to increase education access to students who are located in 
different geographical regions indicates that the global tertiary education system is converging towards providing equitable and inclusive education to everyone, irrespective of their location, age, gender, and background (UNESCO 2020; Aarts et al. 2020). To a large extent, this approach to the delivery of the higher education has addressed the discrimination that existed in the delivery of higher education since the colonial period and has eliminated the geographical barriers faced by students in acquiring high quality education (Chauhan 2020; Herodotou et al. 2020). Student retention in the face-to-face courses is usually higher than the distance and flexible learning courses. The instructors and higher education leaders can design the curriculum and instruction for the distance learning courses by considering the constraints, challenges, and the background of the distance learners (Chauhan 2020; Herodotou et al. 2020). For instance, as compared to the faceto-face students, the distance learners are not able to access the campus resources as the faceto-face students can access, and this places them at a resource disadvantage position. In such circumstances, the universities use a robust online interactive platform to foster online learning.

- Health and leisure activities: There is a wide disparity that exists in the availability of healthcare services to students from different income brackets. Many tertiary education institutions are providing healthcare services to the students free of cost as the health status of students vastly influences their academic performance (Meier et al. 2007; Fullerton 2011). Due to the demanding nature of the higher education courses, students must socialize with other students who are facing similar stressors (Meier et al. 2007; Fullerton 2011). Team building and sports activities increase social interaction and break barriers that inhibit students from different backgrounds from sharing their experiences and problems that they may be facing in a course. In addition to this, the leisure activities also provide students with an opportunity to discuss the new ideas and topics that they have learnt in their courses and the relevance of these topics to their everyday livelihood (Meier et al. 2007; Fullerton 2011).

\section{Student Retention Strategies: The Global Context}

Generally, the higher education institutions are using both business and corporate-level strategies to reach out to face-to-face, blended, and online learning students. To enhance the relationship between educational institutions and students, the universities need to integrate student retention strategies with the business and corporate-level strategies (Melewar and Akel 2005; Curtis et al. 2009; Hanson et al. 2017). This strategic action of the higher education institutions ensures that the delivery of higher education is equitable and inclusive. Higher education institutions that serve both the international and domestic markets can use cost leadership, differentiation, focused cost leadership, focused differentiation and integrated cost leadership, and differentiation strategy to address factors driving the reasons behind students leaving their education (Melewar and Akel 2005; Curtis et al. 2009; Hanson et al. 2017). Increasing student enrolment in the tertiary enrolments is not only sufficient, and there should be measures designed to ensure that students can complete their tertiary education successfully. The strategic plan of a higher education indicates the plans of the institution to provide tertiary education that is inclusive and equitable to everyone in society (Melewar and Akel 2005; Curtis et al. 2009; Hanson et al. 2017). As far as the cost leadership strategy is concerned, the leaders of the higher education institutions can implement cost leadership strategy to address the rising cost of higher education faced by the higher education institutions (Melewar and Akel 2005; Curtis et al. 2009; Hanson et al. 2017). A focused cost leadership strategy is usually implemented on specific programs or geographic markets due to changes in the economic, political/legal, demographic, sociocultural, technological, and global factors. The focused cost leadership strategy may be implemented by higher education institutions 
that have campuses in several geographical regions, and the needs of the students are different based on the differences in the geographic regions. Differentiation and a focused differentiation strategy is used by the higher education institutions to provide courses that are internationally accredited and recognized by the international accreditation agencies (Melewar and Akel 2005; Curtis et al. 2009; Hanson et al. 2017). One of the benefits of offering courses that are internationally recognized is that it allows students with superior competencies and capabilities that increase their chances of employability both locally and internationally. Generally, all students desire to attend tertiary institutions that provide highquality education and at affordable prices. Course fees and quality of education are the two critical factors driving student's decisions to continue their studies with an institution or join a competing institution (Melewar and Akel 2005; Curtis et al. 2009; Hanson et al. 2017).

Furthermore, higher education institutions are diversifying their scope of operations to provide high-quality inclusive education. This involves designing courses that are flexible and meets the needs of students based in the international markets. The SDG on equitable and inclusive education can easily be achieved if higher education institutions implement a corporate-level strategy together with the business-level strategy. Achieving this strategy mix will involve implementing related diversification strategies that will reduce the cost of fees, and international students, particularly the ones from the developing countries will be facing less pressure from the high cost of international student fees (Curtis et al. 2009; UNESCO 2020; Aarts et al. 2020). The differences in the exchange rate that exists between developed and developing countries usually place students from the developing countries at a resource disadvantage as the international student fees become extremely high when converted in the local currency (Curtis et al. 2009; UNESCO 2020). Numerous universities around the world have diversified their scale of operations by venturing in bookselling and publishing business. This cost saving that the universities are able to achieve is transferred to the students in the form of low tuition fees.

\section{Quality Education and Factors Driving Student Retention in Higher Education Institutions}

The international efforts on providing highquality tertiary education have significantly increased, and this is evident by the high number of tertiary enrolments. A national strategy on increasing tertiary enrolments is not enough for realizing the SDGs on inclusive and equitable education to all gender groups. Resources and opportunities for higher education accessibility should be provided, both for males and females. The Gender Parity Index captures the parity in learning opportunities that exist between the boys and girls. A Gender Parity Index less than one shows that girls are disadvantaged in terms of accessibility of higher education learning opportunities and vice versa. Table 3 captures the data on the Gender Parity Index for different regions of the world.

Table 3 shows that the regional Gender Parity Index for East Asia and the Pacific, Europe and Central Asia, high income, Latin America and the Caribbean, and middle-income countries is higher than one. In contrast, the index for heavily indebted poor countries, least developed countries, and low-income countries is less than one. These statistics indicate that the low Gender Parity Index for the heavily indebted poor countries, least developed countries, and low-income countries clearly implies the countries in these regions need to increase the scope and scale of opportunities that they are providing for women and minority groups in society.

The statistics on the Gender Parity Index provides a number of lessons that could be learnt by the policy makers and higher education providers. One of the major lessons is that achieving the SDG on quality education not only involves increasing student enrolment but it involves addressing the specific barriers faced by females in completing their tertiary education. 
Student Learning Experience and Student Retention Strategies: A Transformative Approach to Quality Education, Table 3 Gender Parity Index

\begin{tabular}{l|l|l}
\hline & Year & 2018 \\
\cline { 2 - 3 } Areas & 2017 & 1.1788 \\
\hline East Asia and the Pacific & 1.1683 & 1.1413 \\
\hline Europe and Central Asia & 1.1414 & 0.6977 \\
\hline Heavily indebted poor countries & 0.6927 & 1.2456 \\
\hline High income & 1.2361 & 1.3009 \\
\hline Latin America and the Caribbean & 1.3026 & 0.7075 \\
\hline Least developed countries & 0.7032 & 0.6186 \\
\hline Low income & 0.6155 & 1.1365 \\
\hline Middle income & 1.1272 & \\
\hline
\end{tabular}

Source: World Bank database (2020)

There are numerous factors that are driving the student retention and attrition rates. Some of these factors are quality of prior education, language, instructor's attitude towards diversity, future job prospects, safety and security, student satisfaction, national and classroom-based assessments, immigrant status, fees structure, accessibility of resources, social class, and demographic factors (Christie et al. 2004; Gupta et al. 2020). As far as the context of the heavily indebted poor countries, least developed countries, and low-income countries are concerned, it is critical that the higher education leaders address the constraints restricting females from completing their higher education. These constraints faced by females in completing their tertiary education differs based on differences in the geographic region. Women in the heavily indebted poor countries, least developed countries, and low-income countries are not able to complete their tertiary education due to lack of support from their family members, government, and academic institutions (Christie et al. 2004; Gupta et al. 2020). The role of government and educational institutions is essential in female tertiary education completion rates as they provide resources that are needed by students to complete their education. In addition to this, awareness programs can be designed to reach out to the communities and areas where there is lack of support for female education (Christie et al. 2004; Gupta et al. 2020).

The statistics on the East Asia and the Pacific, Europe and Central Asia, high income, Latin
America and the Caribbean, and middle income shows a satisfactory picture that tertiary education opportunities for women in these countries are high as compared to the poor low-income regions around the world. However, this is not a perfect picture of reality as women are still underrepresented in specific fields and overrepresented in other fields. Irrespective of women's education level, they are still bullied and harassed at the workplace (Olson-Strom and Rao 2020).

To increase student retention rates in the higher education institutions, and provide higher education that enables individuals to become lifelong learners, the following retention strategies can be implemented:

- Academic support programs: The educational support programs for the students are designed to provide all-rounder support to students to facilitate a healthy learning process (Schuetze and Slowey 2002; Cherrstrom et al. 2019). It is designed to increase a student's capability to enhance their social interaction and fit in diverse learning environments. Some of the examples of these academic support programs are as follows:

- Mentoring program

- Buddy program

- International student support program

- Workshops and seminars

- Provision of capable resources: Equitable distribution of academic resources, such as computer labs, library facilities, and lecture 
and tutorial rooms provide equal opportunities to all students, irrespective of their social class and income status (UNESCO 2020; Aarts et al. 2020). Effective alignment of the higher education resources to the delivery of tertiary education ensures that the student needs related to the completion of course assessments is adequately met via the provision of highquality institutional resource inputs (UNESCO 2020; Aarts et al. 2020). Some of the complementary resources provided by the tertiary education institutions are as follows:

- Medical center services

- Wellness and fitness center

- Cafeteria

- Campus security

- Campus housing

- High quality of instruction delivery: There is a mix of factors that influences the quality of higher education instruction delivery (Chauhan 2020; Herodotou et al. 2020). These factors include the availability of interactive information computer technology, education and teaching background of the instructor, support staff and facilities, and student to teacher ratio (Chauhan 2020; Herodotou et al. 2020). The interaction amongst these factors determines how well the instructor is able to communicate the course contents to the students and the student's ability to relate to and grasp the wealth of knowledge that is disseminated to them. Unfortunately, students enrolled in the distance learning courses find it challenging to fulfill the requirements of the internationally recognized and highly competitive distance learning courses offered by universities around the world (Chauhan 2020; Herodotou et al. 2020).

- Provision of scholarships and subsidizing higher education fees: The provision of scholarships by the tertiary institutions and the government influences tertiary education enrolment and completion rates (UNESCO 2020; Aarts et al. 2020). Many students are not able to complete higher education studies because they are not able to finance their education. Low income and heavily indebted countries are facing severe challenges associated with the disparities in the provision of opportunities for higher education, particularly to women and the disadvantaged groups (UNESCO 2020; Aarts et al. 2020). One of the best strategies that can be adopted by the higher education institutions and the policymakers is to design special tertiary education financing schemes for the underprivileged in society. These scholarship schemes will eliminate all forms of resource constraints that is restricting the financially disadvantaged from completing their tertiary education.

\section{Challenges Faced in Retaining Disabled and Mentally Challenged Students}

Quality education improves the livelihood of disabled and mentally challenged individuals, as it makes this cohort of students realize their importance and contribution to socioeconomic decisions of the nation (Lipka et al. 2019). Despite the importance of higher education in empowering the disabled and mentally challenged individuals, there is still a great deal of effort needed to provide equitable and inclusive education to this cohort of individuals in society. Universities have shown remarkable efforts in providing inclusive education to the disabled and mentally challenged students; however, the retention rate of students from this cohort is very low (Veitch et al. 2018). Due to the nature of the competitive work environment, the disabled and mentally challenged students have to work with individuals from diverse backgrounds; therefore, the higher education prepares physically and mentally disadvantaged students to be part of the demanding workforce. The learning needs of the disabled and mentally challenged individuals are different from other students. The higher education leaders and practitioners must understand these varied needs of the disabled and mentally challenged individuals and provide the best resources to facilitate higher education learning. 
It is not uncommon for disabled and mentally challenged students to be easily alienated by their classmates (Moriña et al. 2020). The challenge is not only in preparing the disabled and mentally challenged students for higher education, but it is mainly preparing all the stakeholders in the institution towards the provision of inclusive and equitable higher education delivery (Kendall 2016).

Furthermore, disabled and mentally challenged students face unique challenges that hinder their progress in higher education studies. Students confirm that they have to work much harder and design a plan for their studies that suits their disabilities (Hadley et al. 2020; Manukumar and Dinesh 2020). Daily work routine and completion of assessments for these students becomes extremely difficult when the faculty members have negative attitudes and opinions against the disabled and mentally challenged students (Moriña and Orozco 2020). The role of the higher education leaders becomes critical here as they have to provide training to the instructors on how to create an interactive and inclusive learning environment for all the students. Instructors also need to recognize the importance of treating everyone with respect and dignity, irrespective of their disabilities and weaknesses (Carballo et al. 2019).

Numerous tertiary institutions have designed specific programs for the "ability-diverse" and "neuro-diverse" students. These programs are specifically designed to provide awareness programs to individuals who need specific care as they have unique needs. Ability-diverse and neuro-diverse students, simply put, are those students who have unique mental and physical disabilities that restrict them from performing normal daily activities (Zeedyk et al. 2019). Investing in these programs imposes several challenges for the tertiary institutions, as the higher education leaders have to prioritize scarce financial resources for the day-to-day operations of the institution (Zeedyk et al. 2019). Ability-diverse and neuro-diverse students need special assistive technology to complete their higher education studies, and most universities, particularly, in the low income and developing countries are struggling to finance the high cost of purchasing these assistive technologies (Zeedyk et al. 2019).

\section{Implications of the Student Retention Strategies on the SDGs}

The global quest towards achieving the SDG on equal access of postsecondary education to everyone can be achieved by the year 2030 if the higher education leaders and administrators recognize the constraints faced by men, women, and minority groups and implement strategies to address these constraints (UNESCO 2020). According to Target 4.4 of the SDGs, there is a global pledge towards increasing the number of youths and adults who have technical skills and knowledge (UNESCO 2020). The modern work environment is highly competitive, and this requires the employees to gain transferable skills that are needed to be a team player, resolve conflicts, and work in a diverse environment (UNESCO 2020). Student retention strategies implemented by the higher education administrators and leaders help to increase student retention in higher education institutions. Without the use of retention strategies, it would be difficult for students to complete their studies and acquire the transferable skills that are needed by them to survive in a competitive work environment.

The low income and developing countries are struggling to provide high-quality education to the tertiary students due to lack of availability of skilled teachers. In addition to this, the provision of high-quality education becomes difficult as the classrooms lack resources to facilitate learning. The role of the international donor agencies and the policymakers is to undertake a thorough assessment of the needs of the tertiary institutions before providing finance for higher education resources. In most of the instances, due to mismanagement of funds, it is common for these resources to be misused and unequally distributed for provision of higher education.

There are numerous areas of improvements that need to be undertaken to retain students in the tertiary institutions, and these are as follows (United Nations 2020): 
- Strengthening the provision of early childhood and teacher education.

- Increase in the number of scholarships available to ability-diverse and neuro-diverse students.

- Creating awareness on the importance of vocational education.

- Provision of facilities and institutions for vocational education.

- Increasing equal accessibility of higher education to disabled, women, and mentally challenged groups.

- Higher education institutions should have strong graduate attributes that help students to acquire transferable skills.

- Upgrading education facilities, such as labs, tutorials rooms, computer labs, and study rooms for students.

\section{Conclusion}

The accessibility of formal education is everyone's right in society. Irrespective of where one is born and their background, one has to meet numerous difficulties to acquire high-quality education. One of the main challenges that everyone faces while completing their tertiary education is the lack of financial resources available to students to pay for their tertiary education fees. These challenges exacerbate if the tertiary student is a female or is a physically or mentally challenged student. Student retention strategies that are implemented in the higher education institutions are designed to eliminate all forms of constraints that students are facing to complete their higher education. These strategies are unique based on the challenges that students are facing; however, there are few generic ones, namely, academic support programs, provision of capable resources, high quality of instruction delivery, and provision of scholarships and subsiding higher education fees. The faculty members, who are directly involved in delivering the higher education courses, play a significant role in creating an equitable and inclusive learning environment for all the students. Poor attitude of faculty staff towards physically and mentally challenged students is one of the main barriers restricting their progression to advanced courses. The higher education administrators, in such situations, should ensure that the teaching staff are skillful and have knowledge experience and qualifications to deliver higher education courses in competitive learning environments.

\section{References}

Aarts H, Greijn H, Mohamedbhai G, Jowi JO (2020) The SDGs and African higher education. In: Africa and the sustainable development goals. Springer, Cham, pp 231-241

Adams AM, Wilson H, Money J, Palmer-Conn S, Fearn J (2020) Student engagement with feedback and attainment: the role of academic self-efficacy. Assess Eval High Educ 45(2):317-329

Astin A (1985) Achieving educational excellence: a critical assessment of priorities and practices in higher education. Jossey-Bass, San Francisco

Carballo R, Morgado B, Cortés-Vega MD (2019) Transforming faculty conceptions of disability and inclusive education through a training programme. Int J Inclu Educ. Retrieved from https://www.tandfonline. com/doi/full/10.1080/13603116.2019.1579874

Chauhan JD (2020) Higher education in india-issues, challenges and suggestions. High Educ. Retrieved from https://rrjournals.com/wp-content/uploads/2020/ 01/33-36_RRIJM200501010.pdf

Cherrstrom CA, Robbins SE, Boden CJ, Bixby J (2019) Need tech? Nontraditional student perceptions of educational technology tools. J Contin High Educ 67(2-3):109-122

Christie H, Munro M, Fisher T (2004) Leaving university early: exploring the differences between continuing and non-continuing students. Stud High Educ 29(5):617-636

Curtis T, Abratt R, Minor W (2009) Corporate brand management in higher education: the case of ERAU. J Prod Brand Manag. Retrieved from https:/www.emer ald.com/insight/content/doi/10.1108/10610420910989 $721 /$ full/html

Fichten C, Olenik-Shemesh D, Asuncion J, Jorgensen M, Colwell C (2020) Higher education, information and communication technologies and students with disabilities: an overview of the current situation. In: Improving accessible digital practices in higher education. Palgrave Pivot, Cham, pp 21-44

Fullerton DS (2011) A collaborative approach to college and university student health and wellness. N Dir High Educ 153(2):61-69

Ghee KL (1990) Enhancing educational achievement through cultural awareness in young Black males. West J Black Stud 14(2):77 
Granville B, Leonard C, Manning J (2000) Information technology and developing countries: potential and obstacles. In: Tokyo club meeting, Munich, pp 19-20

Gupta SK, Antony J, Lacher F, Douglas J (2020) Lean Six Sigma for reducing student dropouts in higher education-an exploratory study. Total Qual Manag Bus Excell 31(1-2):178-193

Hadley W, Hsu J, Addison MA, Talbot D (2020) Marginality and mattering: the experiences of students with learning disabilities on the college campus. In: Accessibility and diversity in education: breakthroughs in research and practice. IGI, USA pp 390-403

Hanson D, Hitt MA, Ireland RD, Hoskisson RE (2017) Strategic management: competitiveness and globalization, 6th Asia Pacific Edition. Cengage Learning, USA

Herodotou C, Rienties B, Hlosta M, Boroowa A, Mangafa C, Zdrahal Z (2020) The scalable implementation of predictive learning analytics at a distance learning university: insights from a longitudinal case study. Internet High Educ. Retrieved from https://www. sciencedirect.com/science/article/pii/S1096751620300 014

International Telecommunications Unions (2020) Statistics. Retrieved from https:/www.itu.int/en/ITU-D/Sta tistics/Pages/stat/default.aspx

Kendall L (2016) Higher education and disability: exploring student experiences. Cogent Educ 3(1):1256142

Kintu MJ, Zhu C (2016) Student characteristics and learning outcomes in a blended learning environment intervention in a Ugandan University. Electron $\mathrm{J}$ e Learn 14(3):181-195

Lipka O, Forkosh Baruch A, Meer Y (2019) Academic support model for post-secondary school students with learning disabilities: student and instructor perceptions. Int J Incl Educ 23(2):142-157

Manukumar HN, Dinesh RN (2020) The problems faced by specially abled children with respect to infrastructure facilities in the district of chamrajanagar. Our Heritage 68(30):6327-6339

Meier S, Stock C, Krämer A (2007) The contribution of health discussion groups with students to campus health promotion. Health Promot Int 22(1):28-36

Melewar TC, Akel S (2005) The role of corporate identity in the higher education sector. Corp Commun Int J 10(1):41-57

Moriña A, Orozco I (2020) Spanish faculty members speak out: barriers and aids for students with disabilities at university. Disabil Soc. Retrieved from https://www. tandfonline.com/doi/full/10.1080/09687599.2020. 1723495

Moriña A, Sandoval M, Carnerero F (2020) Higher education inclusivity: when the disability enriches the university. High Educ Res Dev. Retrieved from https:// www.tandfonline.com/doi/full/10.1080/07294360. 2020.1712676

Olson-Strom S, Rao N (2020) Higher education for women in Asia. In: Diversity and inclusion in global higher education. Palgrave Macmillan, Singapore, pp 263-282

Robotham D (2008) Stress among higher education students: towards a research agenda. High Educ 56(6):735-746

Roksa J, Deutschlander D, Whitley SE (2020) Parental validation, college experiences, and institutional commitment of first-generation and low-income students. J Stud Aff Res Pract 1-15. https://www.tandf online.com/doi/full/10.1080/19496591.2019.1699105

Schuetze HG, Slowey M (2002) Participation and exclusion: a comparative analysis of non-traditional students and lifelong learners in higher education. High Educ 44(3-4):309-327

Sife A, Lwoga E, Sanga C (2007) New technologies for teaching and learning: challenges for higher learning institutions in developing countries. Int J Educ Dev ICT 3(2):57-67

Simac J, Marcus R, Harper C (2019) Does non-formal education have lasting effects? Compare J Comp Int Educ. Retrieved from https://www.tandfonline.com/ doi/full/10.1080/03057925.2019.1669011

Straus C (2020) The privileged poor: how elite colleges are failing disadvantaged students. Cato J 40(1):249-250

UNESCO (2020) Sustainable Development Goal. Retrieved from https://sdg4education2030.org/the-goal

United Nations (2020) Sustainable Development Goals on Quality Education. Retrieved from https://www.un.org/ sustainabledevelopment/education/

Veitch S, Strehlow K, Boyd J (2018) Supporting university students with socially challenging behaviours through professional development for teaching staff. J Acad Lang Learn 12(1):A156-A167

World Bank (2020) World Development Indicators. Retrieved from http://data.worldbank.org/data-catalog/ world-development-indicators

Zeedyk SM, Bolourian Y, Blacher J (2019) University life with ASD: faculty knowledge and student needs. Autism 23(3):726-736 